\title{
The New Regionalism in the Americas: The Case of Mercosur
}

\author{
Antoni Esteradeordal \\ Inter-American Development Bank \\ Junichi Goto \\ Kobe University \\ Raul Saez \\ Ministry of Finance in Chile
}

\begin{abstract}
This paper takes seriously the recent claim made by Ethier (1998) that the New Regionalism reflects the success of the multilateral trading system, not its failure. In fact, the New Regionalism represents a qualitative departure of the old regionalism in several respects, in particular, its development has taken place in a very different international economic environment. Moreover, the traditional Vinerian paradigm is no longer the primary analytical framework for its evalua-tion. We use this novel approach to analyze the case of one of the most important experiences in regional integration, the formation of the Mercado Común del Sur (MERCOSUR). The paper carefully documents the main stylized facts of the development of MERCOSUR arguing that this makes this type of agreement a prime example of the New Regionalism. Our conclusions are consistent with Ethier's paper, that is, regionalism can play a key role in expanding and preserving the liberal trade order.
\end{abstract}

- JEL Clasifications: F15

- Key Words: Regionalism, Customs, Free Trade Area, Mercosur

\footnotetext{
*Corresponding Address: Antoni Estevadeordal is a Research Economist at the Integration, Trade and Hemispheric Issues Division of the Inter-American Development Bank, 1300 New York Ave., NW, Washington, D.C. 20577 USA. Tel: +1-202-623-2614 Fax: +1-202-623-3030. Email: antonie@iadb.org. Junichi Goto is Professor of Economics at Kobe University, Research Institute for Economics and Business Administration, 2-1, Rokkodai-cho, Nada-Ku, Kobe 657, Japan, Tel: +81-70-803-7007, Fax: +81-78-8616434, Email: jgoto@ rieb.kobe-u.ac.jp. Raul Saez is International Coordinator, Ministry of Finance (Chile) Teatios 120, Santiago, Chile, Tel: +2-6755818, Fax: +2-6964798, Email: rsaez@minhda.cl. (C)2001-Center for International Economics, Sejong Institution, All Rights Reserved.
} 


\section{Introduction}

The world is undergoing a second wave of regionalism. In contrast to the first wave of regionalism in the 1950s and 1960s, which was mostly short-lived except in the case of Western Europe, we have witnessed many successful attempts to form integrated trading areas all over the world since the mid-80s. Those recent attempts are often referred to as the "New Regionalism." In Europe, a fairly successful attempt to form a single market by 1992 (EC92) developed into deeper economic integration that involves monetary unification. In Asia and the Pacific, many countries are united into a much looser economic union called the Asian Pacific Economic Cooperation (APEC), and they agreed to achieve free trade and investment in the region by 2010 for industrialized countries and by 2020 for developing countries. In North America, the United States, Canada, and Mexico formed the North American Free Trade Agreement (NAFTA) in 1994, and the three countries agreed to abolish tariff and non-tariff barriers in the region by 2009.

Also in Latin America, various attempts have been made to form free trade areas at the subregional level. Probably, one of the most important initiatives has been the formation of the Mercado Común del Sur (MERCOSUR) by Argentina, Brazil, Paraguay, and Uruguay. The arrangement to form a customs Union (CU) among the four countries was agreed upon in 1991 in the Treaty of Asunción. As discussed in detail below, since the end of 1980s, the tariff rates, both MFN tariffs and preferential tariffs, have been drastically reduced, and the amount of international trade, both intra-regional and extra-regional, have dramatically increased. Other bilateral and sub-regional groupings have also made substantial progress in the same direction. Finally, the launching of the Free Trade Area of the Americas (FTAA) in 1995 is now in full negotiations with the potential of becoming the largest, in a geographical sense, experiment in the New Regionalism approach to economic integration.

In view of the increased importance of MERCOSUR in the Latin American economy, the purpose of this paper is to present some stylized facts about MERCOSUR and clarify how MERCOSUR fits the description of the New Regionalism, emphasizing its differences from other, more traditional, FTAs or CUs.

This paper takes a very different approach from other recent studies on MERCOSUR $^{1}$ in two important aspects. First, we analyze MERCOSUR from a

\footnotetext{
${ }^{1}$ See Yeats (1998) and Winters and Chang (1999), for example.
} 
broader perspective than most studies. A key feature in the development of MERCOSUR has been the reduction of nondiscriminatory MFN tariffs simultaneously with a reduction of intra-area preferential tariffs. In this sense, MERCOSUR fits perfectly the stylized facts of what Ethier (1998) calls the New Regionalism. The following summarizes Ethier's stylized facts of New Regionalism and how they apply to MERCOSUR:

- New regionalism typically involves one or more countries linking up with a large country. In the case of MERCOSUR, Brazil is the larger country, while the second economy, Argentina, is also large compared to the small economies in the group (Paraguay and Uruguay).

- Typically, the smallest countries have recently made, or are making, significant unilateral reforms. In the case of MERCOSUR, all of the member countries have undertaken major unilateral reforms since the late 1980s.

- Dramatic moves to free trade between members are not featured: the degree of liberalization is typically modest. Thus the Vinerian paradigm is not a natural starting point. Even in the case of MERCOSUR, where the internal liberalization has been more ambitious, it is not large relative to the unilateral liberalization by each member.

- The liberalization achieved is primarily by the small countries, not by the large country: The agreements are one-sided. Ethier uses MERCOSUR as an exception in this case, pointing out that Brazil has made concessions at least as large as those of the smaller members. However, he notes that Brazil is also a reformer.

- Regional arrangements often involve deep integration: the partners seldom confine themselves to reducing or eliminating trade barriers, but also harmonize or adjust diverse assortments of other economic policies. This is also a feature of MERCOSUR where there is an ongoing agenda for deepening the regional agreement towards a comprehensive economic union.

- Regional arrangements are regional geographically: The participants are neighbors. This is a trivial feature in the case of MERCOSUR.

In this paper, we carefully document some of these stylized facts. For example, from 1985 to 1997, the average MFN tariff in MERCOSUR countries declined from 37.2 percent to 12.3 percent, while the average tariffs imposed on partners declined from 35.2 percent to 4.2 percent. In view of such a large magnitude of MFN tariff reduction and the relatively modest magnitude of additional reduction of preferential tariffs, the traditional attempts to analyze the impact of preferential tariff reduction alone do not seem to give a comprehensive picture of the impact of trade policy changes. Therefore, we concentrate our analysis on the impact of 
the preferential tariff reduction that accompanies the unilateral MFN tariff reductions in MERCOSUR countries.

Second, closely related to the first point, we analyze the MERCOSUR over a longer time span than most studies. While many studies examined the impact of MERCOSUR for just a few years after 1995 (or after 1991), we will incorporate the developments since the late 1980s into our analysis, because, we believe, trade policies have to be evaluated over a long period of time, and trading arrangements do not show their full impact instantaneously. For example, aggressive trade liberalization was underway in the years before the Treaty of Asunción (in 1991), and the full-fledged liberalization under MERCOSUR is expected to be completed by $2006^{2}$.

\section{Trade Policy Reform in the MERCOSUR Countries}

A distinguishing feature of the reduction and elimination of trade barriers among the MERCOSUR countries is that this process overlapped with the latter stages of unilateral trade policy reforms initiated earlier in each country. These led to significantly lower import tariffs, reduced dispersion of rates and the scrapping of most non-tariff barriers for imports from third countries. The common external tariff (CET) adopted in 1995 by MERCOSUR implies substantial overall tariff reduction compared to those existing in the member countries in the 1980s.

In this section we provide, first, some stylized facts on how trade was unilaterally liberalized in each of the four countries in the 1990s. Not only import restrictions were reduced. Export taxes and subsidies, as well as other trade policy instruments have been reformed. However, the focus here is on import policy. We then turn to preferential trade liberalization in the MERCOSUR area, as well as the steps taken in the direction of establishing a customs union.

In Tables 1 to 3 we report the evolution of the external tariffs, internal (preferential) rates as well as the preference margin for the four countries during the period under analysis. The same information is plotted on a yearly basis in Figures

\footnotetext{
${ }^{2}$ In an earlier (and longer) version of this paper, we have presented a formal analysis of the welfare impact of Mercosur using a simple three-country model (see Estevadeordal, Goto and Saez (2000) for details). As shown there, since Mercosur countries unilaterally reduced external MFN tariffs as well intraregional tariffs, they approach a situation towards free trade, where not only member countries but also outside countries are better off. In this sense, Mercosur-type of trading agreements seems to be better than regular trading blocs, because in the former the adverse effect due to trade diversion is smaller, and the positive effect due to trade creation is larger, than the latter type of arrangement.
} 
Table 1. Mercosur: Average MFN Tariffs (1985-1997)

\begin{tabular}{|c|c|c|c|c|c|}
\hline & 1985 & 1988 & 1991 & 1994 & 1997 \\
\hline \multicolumn{6}{|l|}{ Argentina } \\
\hline Average & 39.20 & 30.83 & 14.22 & 15.42 & 14.13 \\
\hline Standard deviation & 9.48 & 10.31 & 6.00 & 8.86 & 6.40 \\
\hline \multicolumn{6}{|l|}{ Brazil } \\
\hline Average & 55.09 & 41.54 & 20.37 & 9.70 & 14.95 \\
\hline Standard deviation & 28.03 & 19.57 & 16.80 & 6.93 & 7.14 \\
\hline \multicolumn{6}{|l|}{ Paraguay } \\
\hline Average & 18.68 & 18.62 & 13.55 & 7.26 & 10.02 \\
\hline Standard deviation & 13.82 & 13.73 & 11.83 & 6.80 & 6.32 \\
\hline \multicolumn{6}{|l|}{ Uruguay } \\
\hline Average & 35.87 & 26.94 & 21.35 & 13.63 & 10.11 \\
\hline Standard deviation & 14.91 & 11.34 & 6.50 & 5.90 & 6.44 \\
\hline MERCOSUR average $^{a}$ & 37.21 & 29.48 & 17.37 & 11.50 & 12.30 \\
\hline
\end{tabular}

Source: Authors calculations on the basis of official data.

Note: ${ }^{a}$ Simple average of the four countries average tariff

Table 2. Mercosur: Preferential Tariffs (1985-1994)

\begin{tabular}{|llrrrrr|}
\hline \multirow{3}{*}{ Argentina } & & 1985 & 1988 & 1991 & 1994 & 1997 \\
& Brazil & 36.6 & 24.4 & 7.2 & 5.1 & n.a. \\
& Paraguay & 35.2 & 22.2 & 7.8 & 7.6 & n.a. \\
& Uruguay & 36.0 & 20.8 & 8.1 & 10.7 & n.a. \\
& Argentina & 51.9 & 30.9 & 10.0 & 3.2 & n.a. \\
& Paraguay & 49.9 & 28.3 & 10.8 & 4.4 & n.a. \\
& Uruguay & 51.1 & 25.1 & 10.7 & 4.9 & n.a. \\
& Argentina & 19.9 & 19.2 & 13.3 & 7.0 & n.a. \\
& Brazil & 19.9 & 19.2 & 13.8 & 7.0 & n.a. \\
& Uruguay & 19.7 & 19.0 & 13.4 & 6.9 & n.a. \\
& Argentina & 34.6 & 21.1 & 15.5 & 12.0 & n.a. \\
& Brazil & 34.6 & 22.0 & 15.8 & 10.0 & n.a. \\
& Paraguay & 33.3 & 22.5 & 14.8 & 9.1 & n.a. \\
\hline
\end{tabular}

Source: Author's calculations based on official data.

1.1 to 1.4. There are four main periods for which to evaluate the tariff policies implemented by the four MERCOSUR countries: (1) pre-1986; (2) 1986 to 1988; (3) 1988 to 1991 ; (3) 1991 to 1994 ; (4) post-1994. In this section, we discuss in detail each one of these four periods with a reference to the specific measures undertaken by each country. The initial period reflects the situation of the external tariffs prior to the process of unilateral liberalization and the launching of the Uruguay Round, while the preferential rates show the degree of preferential 
Table 3. Mercosur: Preference Margins (1985-1994) []

\begin{tabular}{|lllcccc|}
\hline \multirow{3}{*}{ Argentina } & 1985 & 1988 & 1991 & 1994 & 1997 \\
& Brazil & 1.5 & 4.6 & 6.0 & 9.5 & n.a. \\
& Paraguay & 2.6 & 6.4 & 5.4 & 7.0 & n.a. \\
& Uruguay & 1.9 & 7.9 & 5.2 & 3.9 & n.a. \\
& Argentina & 1.9 & 7.4 & 9.6 & 6.2 & n.a. \\
& Paraguay & 3.2 & 9.2 & 8.8 & 5.1 & n.a. \\
& Uruguay & 2.5 & 12.1 & 8.9 & 4.5 & n.a. \\
& Argentina & 0.2 & 0.7 & 1.2 & 0.7 & n.a. \\
& Brazil & 0.2 & 0.7 & 0.8 & 0.6 & n.a. \\
& Uruguay & 0.3 & 0.9 & 1.1 & 0.7 & n.a. \\
& Argentina & 0.7 & 4.9 & 5.1 & 1.5 & n.a. \\
& Brazil & 0.7 & 4.1 & 4.9 & 3.4 & n.a. \\
& Paraguay & 1.6 & 3.5 & 5.6 & 4.1 & n.a. \\
\hline
\end{tabular}

Source: Authors' calculations based on official data.

Note: Preference Margin is defined as $\{[(1+M F N$ Tariff $) /(1+$ Pref. Tariff $)]-1\} \times 100$.

liberalization achieved under the LAIA framework. In this initial stage, external tariffs were very high and preference margins had been almost completely eroded. The period from 1986 to 1988 can be seen as the birth of the future MERCOSUR agreement with the signature of the Economic Integration and Cooperation Program between Argentina and Brazil. To some extent, the MFN tariff peaks around 1987 (in particular for Argentina and Brazil) are probably due to the negotiations on the initial tariff base rates to be used as the starting point during the Uruguay Round market access negotiations.

By the end of 1988 Argentina and Brazil reduced their tariffs, external and internally, producing the largest annual cut for the whole period, resulting in important levels of preference margins. This process of external liberalization, matched with intra-bloc tariff reduction, continued until 1991 with the signature of the Treaty of Asunción (see below) creating the basis for the MERCOSUR agreement. The year 1991 was an inflexion point of this process towards a Common External Tariff (CET). After a process of unilateral liberalization and the creation of an intra-regional free trade area, the four countries engaged in negotiations for a CET with full intra-market liberalization. As common in any CET formation, preference margins slightly increased over this period, since there is usually a stable target in terms of a common external tariff and a deepening of the intra-regional liberalization to conform with a free trade goal of zero tariffs among members. In a later stage further external liberalization, lowering the external 
Figure 1.1. Evolution of External and Internal Tariffs in Mercosur Countries.

Argentina (1985-1995).

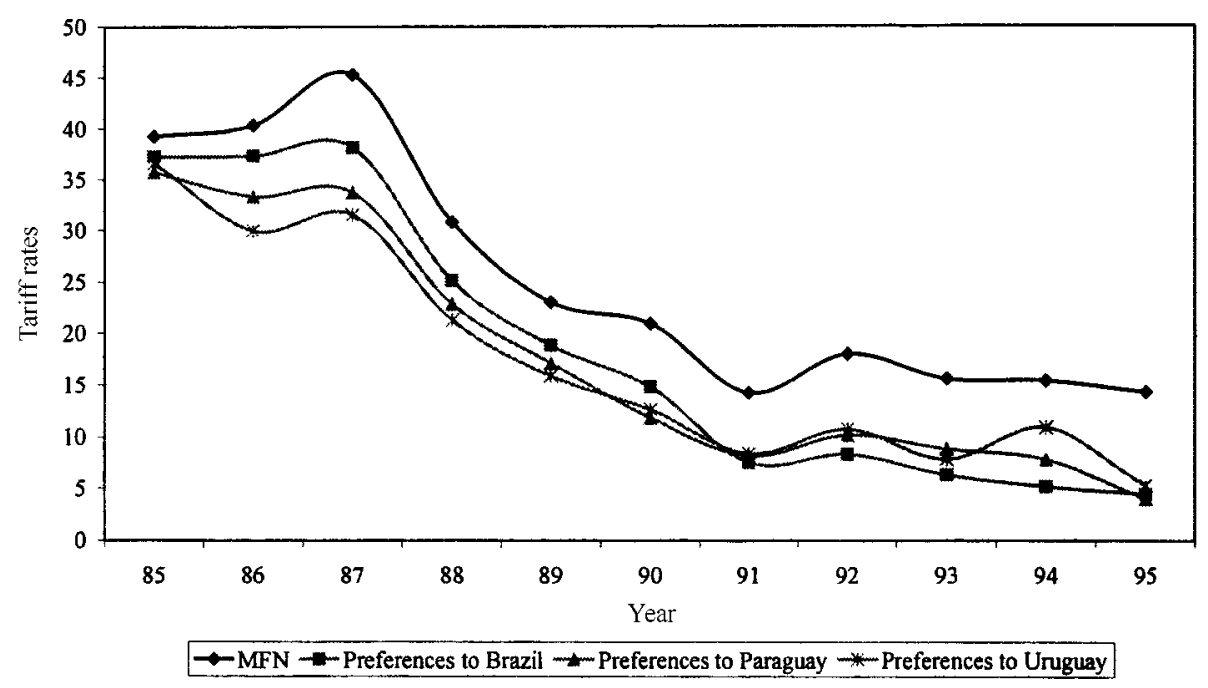

Figure 1.2. Evolution of External and Internal Tariffs in Mercosur Countries.

Brazil (1985-1995)

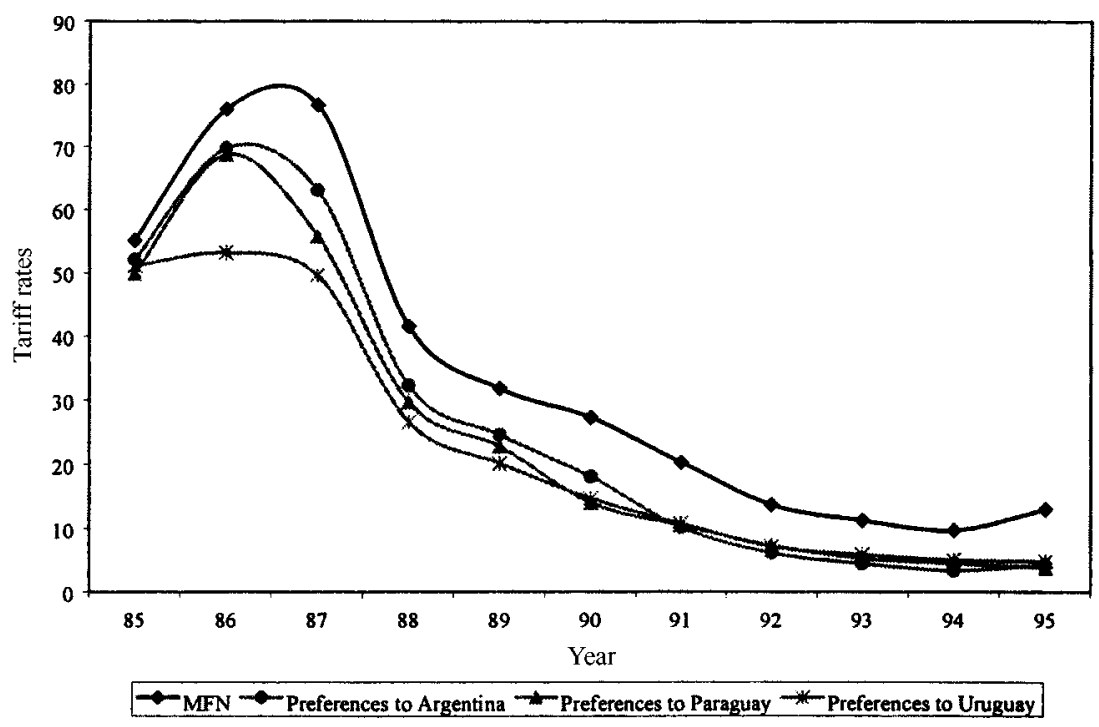

tariff to third countries, could take place as part of a harmonized regional policy in the context of a hemispheric agreement or a new round of multilateral trade negotiations.

\section{A. Unilateral Trade Policy Reform in the MERCOSUR Countries}

The debt crisis of 1982, dissatisfaction with the results of import-substitution 
Figure 1.3. Evolution of External and Internal Tariffs in Mercosur Countries. Paraguary (1985-1995).

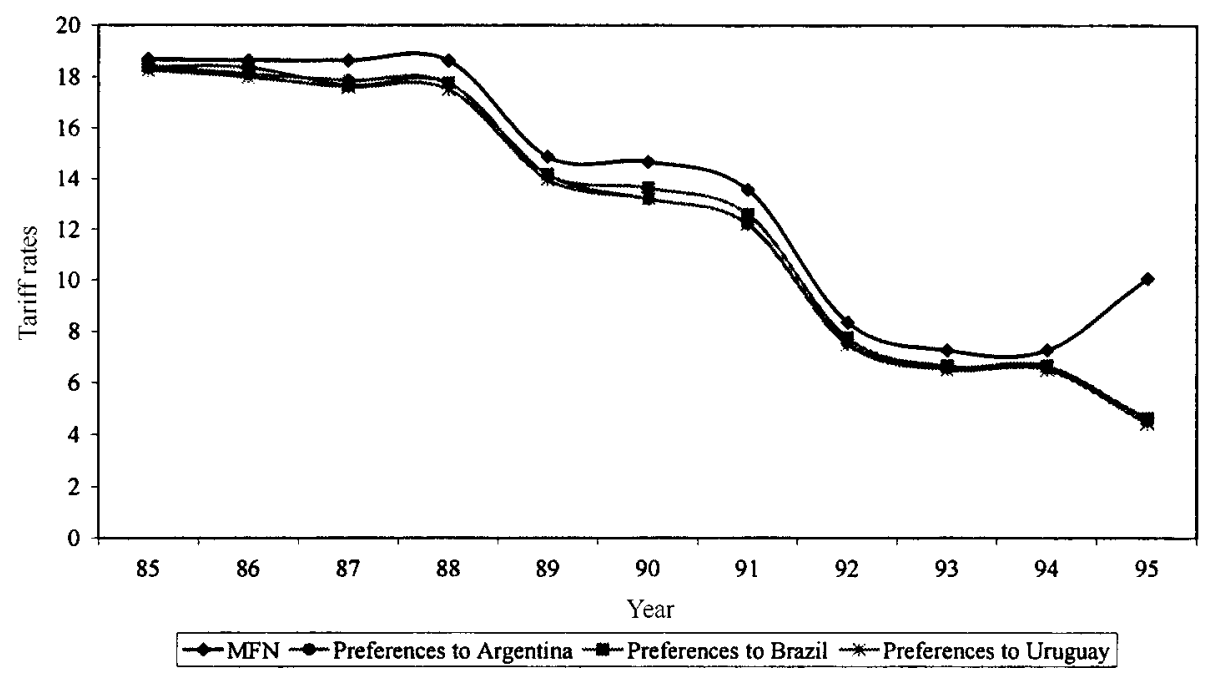

Figure 1.4. Evolution of External and Internal Tariffs in Mercosur Countries. Uruguary (1985-1995).

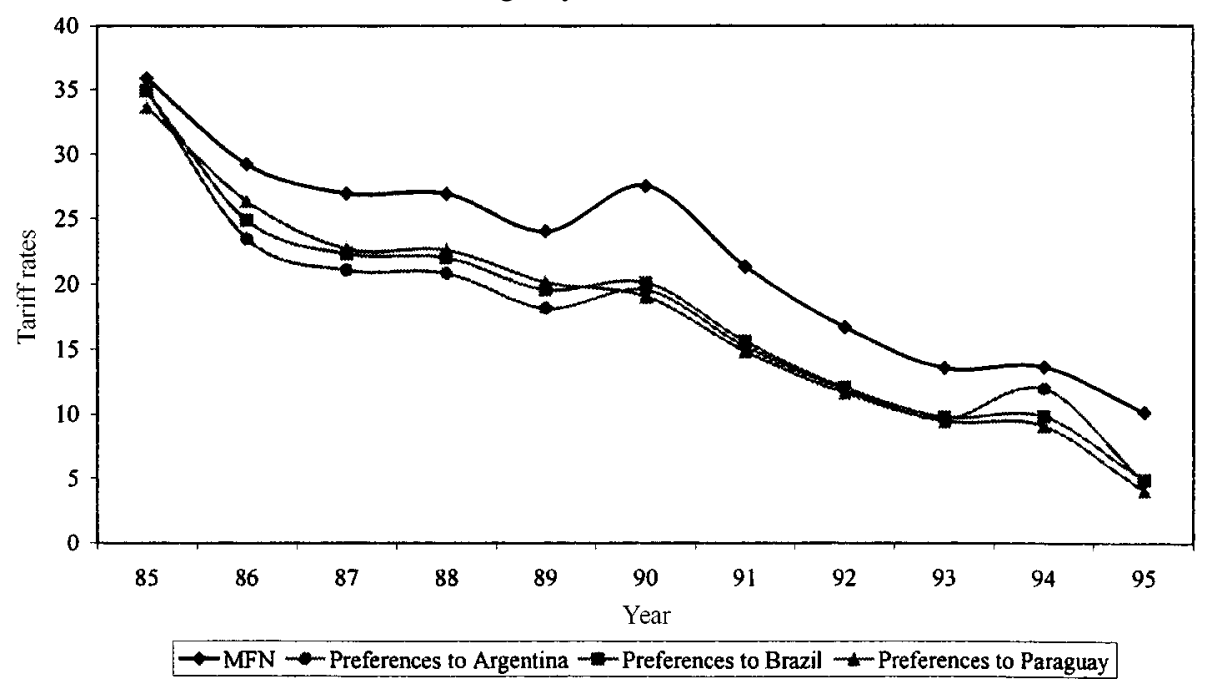

strategies and the acknowledgement that all effects on resource allocation of trade policies characterized by high and dispersed import tariffs, widespread use of quantitative restrictions and other non-tariff barriers and granting multiple exemptions to import restrictions were no longer clear, led to the reform and liberalization of trade policies throughout Latin America. The process started in isolated cases in the mid-1980s but was generalized in the early 1990s. The 
countries that today form the MERCOSUR were not an exception. At different speeds, not always linearly, and beginning in different years, Argentina, Brazil, Paraguay and Uruguay unilaterally reduced tariff levels, eliminated quantitative restrictions and, in general, reformed their trade regimes in the direction of opening their economies. The partial adoption of MERCOSURs common external tariff (CET) in 1995 did not lead, on average, to additional tariff reductions.

Argentina began to reduce tariffs and non-tariff barriers in 1988-89. In 1989, at the start of the reforms, two-thirds of the tariff lines under quantitative restrictions, which covered about 60 percent of the lines, were liberalized (Berlinski, 1994; Primo Braga, Nogues and Rajapatirana, 1995). Between 1989 and 1990 these restrictions were further eliminated. Only a few items in the auto industry remained covered by such restrictions. In mid-1990 the import licensing requirement was revoked, making the granting of licenses automatic except for those items that remained under quantitative restrictions (i.e., those in the auto industry).

From October 1988 on, import tariffs were modified on several occasions. In the reform introduced in that month, the range of tariff rates went from 15 to 53 percent to 0 to 40 percent for most imports. The maximum tariff rate for motor vehicles was reduced from 115 percent to 40 percent. However, specific tariffs were introduced for a number of goods, including automobiles and textiles. In October 1989 all rates above 40 percent were reduced to that level and rates between 14 and 40 percent went down by 7 percentage points, but a 5 percent tariff was applied on goods previously free of tariff. At the end of 1989, the maximum tariff rate was lowered to 30 percent (except for the ad-valorem equivalent of some specific tariffs). The removal of specific tariffs began during 1990. In January 1991 a uniform tariff of 22 percent was adopted, with some exceptions with a tariff of 0 percent.

When the Convertibility Plan was introduced in April 1991, a new tariff structure with three levels $(0,11$ and 22 percent) was put in place. All remaining specific tariffs were replaced by ad-valorem rates. In June, tariffs on the auto products subject to quota and on electronic products subject to reference prices until then were raised to 35 percent (GATT, 1992a). In November 1991, some items with zero tariff had it replaced by a 5 percent rate and the 11 percent tariff was increased to 13 percent. Thus, by the end of 1991, a five-rate $(0,5,13,22$ and 35 percent) structure was in place. The number of rates was further increased to nine in October 1992, but with levels from 0 to 20 percent. After that, there were no general changes in the basic import tariff rates until the introduction of the 
MERCOSUR CET in 1995. Argentina, like the other members of MERCOSUR, has two types of exceptions to the application of the CET. ${ }^{3}$ First, there are those exceptions contained in a national List of Exceptions. The national tariff for these products is to gradually converge to the CET rate by December 2000. In the case of Argentina this will imply both higher and lower rates than the starting national tariff. According to WTO calculations, the average tariff rate is to fall to 11 percent in 2006 when the CET will be fully adopted (WTO, 1999). Second, there are the exceptions for capital goods, informatics and telecommunication products, sugar and the auto industry that are common to all members. The $\mathrm{CET}^{4}$ on capital goods must be adopted by January 1, 2001 and the CET on informatics and telecommunications products by January 1, 2006. Argentina is to apply the common policy for sugar production and the auto industry in 2001 and 2000, respectively.

In addition to the basic tariff, Argentina has had a statistical tax that acts as a tariff and was modified on several occasions during this period. In October 1992, it was raised from 3 to 10 percent, but not applied to capital goods not produced domestically (after May 1993 all capital goods imports were exempted from the tax), and to products negotiated in a bilateral agreement with Uruguay. Tariff preferences under the MERCOSUR liberalization program did not include the statistical tax (i.e., it was still levied on them), however in May 1993 imports from Paraguay were exempted from this tax. It was eliminated in January 1995, but reinstated in March with a rate of 3 percent for all imports from non-MERCOSUR countries, excluding imports of fuels and capital goods. The statistical tax was successfully challenged in the WTO in 1997 and Argentina reduced it to 0.5 percent it in January 1998 as MERCOSUR raised its CET by three percentage points. ${ }^{5}$ Since 1993, Argentina has also applied specific import tariffs on textiles, apparel and footwear imported from outside MERCOSUR.

In early 1991 Brazil put in place a program to reduce tariffs annually with final target rates to be reached in 1994. However, some reductions were moved forward so the program was completed by July 1993. The range of tariff rates went from 0-105 percent in 1990 to 0-85 percent in 1991, 0-55 percent at the end of 1992 and to 0-40 percent in July1993 (WTO, 1997a). As a result, the average tariff went from 42 percent in 1988 to 20 percent in 1991, and 10 percent in 1994 (WTO,

\footnotetext{
${ }^{3}$ For additional details see the following section.

${ }^{4}$ The maximum CET for capital goods is 14 percent and for informatics and telecommunication products it is 16 percent.

${ }^{5}$ There was no net effect on non-MERCOSUR imports as Argentina exempted them from paying preshipment inspection costs.
} 
1997a). Prior to the reduction in tariffs, non-tariff barriers were relaxed: in May 1990 the list of forbidden imports was abolished and in July the quantitative restrictions were removed so that import licenses began to be issued automatically (Fritsch and Franco, 1993). The coverage of quantitative restrictions fell from 39 percent of tariff lines to minimal (Primo Braga, Nogues and Rajapatirana, 1995).

In January 1995 Brazil adopted the MERCOSUR CET. As in the case of the other member countries, Brazil has exceptions to the CET and has also modified its tariffs for non-MERCOSUR imports on the basis of those exceptions. In the case of capital goods, Brazils rates are above those of the CET (WTO, 1997a) and should converge to this level (14 percent) by 2001. Tariffs on informatics and telecommunications products are to converge to the common level (16 percent) by 2006. Finally, there is Brazils list of exceptions that initially included 175 items, but by mid-1996 had been expanded to 233 items. The rates for these imports are both above and below those of the CET (INTAL, 1996), and convergence must be achieved by January 2001. In April 1995, Brazil was allowed up to 150 additional items as exceptions to the CET for one year. This list initially included about 100 items, with tariffs of up to 70 percent in the case of textiles and some consumer products. When it expired in April 1996, safeguard measures were invoked to keep tariffs of up to 70 percent on textiles and toys (WTO, 1997a).

The import policy for automobiles underwent several changes in 1995. In March, tariffs were raised to 70 percent for vehicles and in June, quotas were imposed on their import as tariffs on parts were reduced. The quantitative restrictions were required to be removed in October as the WTO ruled that the invocation of safeguards was not justified (WTO, 1997a).

Prior to the reforms introduced in the early 1990s, Paraguay's trade regime was characterized by high and dispersed tariff rates and the extensive use of import bans. In May 1989, import prohibitions were abolished for several goods, and tariffs on certain imports were lowered. By July 1993, the number of products with imports prohibited was down to 69 items. Major tariff reforms were introduced in June 1992. The new tariff structure had three basic rates: 0 percent for inputs, 5 percent for capital goods and 10 percent for consumer goods, with the exception of automobiles with rates of 15 and 20 percent. These tariff rates were not changed until the adoption of the MERCOSUR CET in January 1995. The latter has implied an increase in Paraguays average tariff. Convergence of the list of exceptions to the level of the CET will also result in an increase in tariffs in the 
case of Paraguay. ${ }^{6}$

Although total import duties in Uruguay were reduced in 1986 and 1987, more significant changes were adopted starting in 1990. In April, the number of total import tariff rates was reduced to four, ranging from 15 to 40 percent. These rates were reduced by 5 percentage points in September 1991, with the exception of the 40 percent rate. In April 1992 and January 1993, the 20 and 30 percent rates were reduced to 17 and 15 percent and 24 and 20 percent, respectively. Other non-tariff barriers on imports such as consular fees, cargo handling charges, import reference prices and minimum export (import) prices have been eliminated or their coverage reduced. The latter remains in force for sugar, textiles and apparel products.

Also, after 1991 all import prohibitions had been eliminated. Uruguay adopted the CET in January 1995, with exceptions, as in the case of the other members of MERCOSUR, which are explained in the following section. The convergence to the MERCOSUR levels will imply an increase in tariffs on capital goods, and both rises and declines in the case of other goods (INTAL, 1996). WTO calculations indicate that the average tariff will reach 11 percent in 2006 when convergence to the CET is completed (WTO, 1998). Uruguay was allowed to exempt certain capital and intermediate goods from the increase of three percentage points in the CET in January 1998.

\section{B. MERCOSUR Trade Policy: Preferential Liberalization and External Tariffs}

The origins of MERCOSUR can be traced to the July 1986 agreement between Argentina and Brazil that established the Economic Integration and Cooperation Program (PICE). The basic components of this agreement were several protocols with lists of negotiated products that were to receive preferential treatment. The agreement also included industry cooperation programs, for example in the capital goods industry. But this was not the first agreement among MERCOSUR countries that led to preferential trade in the region.

Since the early 1980s and within the LAIA ${ }^{7}$ framework, Argentina, Brazil, Paraguay and Uruguay had signed a number of bilateral agreements basically structured as positive lists of products that obtained tariff preferences (with variable margins of preference, in some cases up to 100 percent of the MFN tariff), as well as exceptions from non-tariff barriers. ${ }^{8}$ In addition to that, several products

\footnotetext{
${ }^{6}$ The WTO estimates that Paraguays average tariff will rise by about two percentage points by the year 2006 when MERCOSURs CET will be fully adopted (WTO, 1997b). According to INTAL (1996) all products in Paraguays national exception list will converge upwards to the CET.
} 
were receiving LAIAs Regional Tariff Preference (PAR), with rates that depended on the country of origin and the country given the preference. ${ }^{9}$ Therefore, prior to the Agreements that formed the basis of MERCOSUR, there was preferential trade among the member countries but its extent was rather limited.

In November 1988, Argentina and Brazil signed the Integration, Cooperation and Development Treaty (TICD) with the objective of gradually removing all barriers to trade in goods and services between the two countries in ten years. However, in July 1990 the two countries decided to reduce to five years the transition to a common market. In August, Uruguay formally requested to fully participate in the common market and Paraguay was invited to join the other three countries. Finally, on March 26, 1991 the four current members of MERCOSUR signed the Treaty of Asunción. Its goal was the creation of a common market by December 31, 1994 through the gradual, automatic and linear reduction of tariffs and non-tariff barriers. In addition to the free movement of goods, there was to be free movement of services and factors of production. A CET was to be established and macroeconomic, sectoral and other policies were to be coordinated.

The trade liberalization program began in 1991 with a minimum preference over MFN tariffs of 40 percent, which Argentina and Brazil had already reached through their previous treaties. This preference was increased every semester by 7 percentage points, until it reached 100 percent in December 1994. In the case of Paraguay and Uruguay the process lasted one more year (until December 1995). Each country had lists of products excluded from the liberalization program, ${ }^{10}$ but these lists were to be reduced by 20 percent at the end of each year so that by December 1994, the free trade area would be completed. ${ }^{11}$ Non-tariff barriers declared by each country were also to be eliminated by December 1994, but this deadline was moved to June 1995.

The trade liberalization program advanced as scheduled, but some goods still

\footnotetext{
${ }^{7}$ Latin American Integration Association (ALADI in Spanish). Its members are Argentina, Bolivia, Brazil, Chile, Colombia, Ecuador, Mexico, Paraguay, Peru, Uruguay and Venezuela.

${ }^{8}$ In some cases, tariff preferences were combined with quotas. Some of these bilateral agreements simply renewed or renegotiated bilateral trade preferences under LAIAs predecessor, LAFTA (Latin American Free Trade Association or ALALC in Spanish).

${ }^{9}$ Other LAIA members also received trade preferences from MERCOSUR members through the PAR and bilateral agreements.

${ }^{10}$ The number of goods excluded from the liberalization program was as follows: Argentina 394, Brazil 324, Paraguay 439 and Uruguay 960.

${ }^{11}$ Again, Paraguay and Uruguay had an additional year to complete this process.
} 
Table 4. Mercosur: Starting Dates of Permanent Trade Regime

\begin{tabular}{|lllll|}
\hline & Argentina & Brazil & Paraguay & Uruguay \\
\hline Free trade area: & & & & \\
Adaptation Regime & Jan 1, 1999 & Jan. 1, 1999 & Jan. 1, 2000 & Jan. 1, 2000 \\
Sugar & 2001 & 2001 & 2001 & 2001 \\
Auto industry & Jan. 1, 2000 & Jan. 1, 2000 & Jan. 1, 2000 & Jan. 1, 2000 \\
Customs union: & & & & \\
National exceptions & Jan. 1, 2001 & Jan. 1, 2001 & Jan. 1, 2006 & Jan. 1, 2001 \\
Capital goods & Jan. 1, 2001 & Jan. 1, 2001 & Jan. 1, 2006 & Jan. 1, 2006 \\
Informatics and & & & & \\
Telecommunications products & Jan. 1, 2006 & Jan. 1, 2006 & Jan. 1, 2006 & Jan. 1, 2006 \\
Sugar & 2001 & 2001 & 2001 & 2001 \\
Auto industry & 2000 & 2000 & 2000 & 2000 \\
\hline
\end{tabular}

Source: INTAL (1996).

remain outside the free trade area (i.e. a tariff still applied in intra-MERCOSUR trade) in the denominated Adaptation Regime (Listas de Adecuación in Spanish), and there are still some non-tariff barriers in place. Most of these goods are intermediate goods, but there are also some consumer goods, and in the cases of Paraguay and Uruguay capital goods such as machinery and equipment are included (INTAL, 1996). ${ }^{12}$ Tariffs for intra-MERCOSUR trade in these goods should be gradually reduced and eliminated by 2000 . Some industries are not subject to free trade across-the-board. Trade in products of the auto industry continues to be regulated by an agreement reached in $1996 .{ }^{13}$ In January 2000 the industry should also be under the free trade regime and protected from imports originating outside MERCOSUR by the CET. Sugar production is also not under tariff-free trade, but by January 2001 it should be under the rules of the customs union.

At a summit in Ouro Preto in December 1994, agreement on the structure and rates of the CET was reached. MERCOSUR adopted an escalating tariff structure with 11 levels, ranging from 0 to 20 percent. However, the CET is applied to 85 percent of the tariff schedule. Each country has a list of exceptions to the application of the CET; for these goods the national tariffs on non-MERCOSUR imports continue to be in use. Their tariffs are to converge gradually and linearly to the CET, by December 2000 for Argentina, Brazil and Uruguay and by Decem-

\footnotetext{
${ }^{12}$ The number of tariff items under this regime varies from 29 for Brazil to 958 for Uruguay (INTAL, 1996).

${ }^{13}$ There is free trade in vehicles and parts between Argentina and Brazil, but assembly plants have to compensate imports with exports to all destinations (INTAL, 1996). So far, agreement on the CET on vehicles (35 percent) and parts (14.9 and 18 percent) has been reached.
} 
ber 2005 for Paraguay. The CET is not applied to certain industries in all countries. This is the case with the auto industry and sugar production, but capital goods and goods of the telecommunication and informatics industries are excluded from the customs union. In the case of capital goods, the tariffs applied by each country must gradually converge to the CET of 14 percent by the year 2001 for Argentina and Brazil and by 2006 for Paraguay and Uruguay. The tariffs on telecommunication and informatics goods will also converge to the CET (with a rate of 16 percent) by 2006 in all countries. Table 4 summarizes the completion of the free trade area and the customs union for each of the members and the industries under special transitional regimes.

In January 1998 the MERCOSUR members agreed to allow an across-theboard temporary increase in the CET by a maximum of three percentage points until December 2000. Countries can maintain the permanent CET rate, as Uruguay has done for some goods (see the previous section).

The largest unilateral reductions in import tariffs had been completed by 1991, the year when the MERCOSUR was established. The internal trade preferences advanced over MFN tariffs that were significantly lower than those that prevailed in the member countries in the 1980s. However, the adoption of the CET did not and will not lead to additional trade liberalization, and in one country resulted in higher tariffs for non-MERCOSUR imports.

\section{Salient Features of MERCOSUR Trade in the Last Decade}

In analyzing the evolution of MERCOSUR intra- and extra-regional trade, and the resulting share of the former in total trade, a number of key factors affecting trade flows must be taken into account. First, as seen previously and emphasized in this paper, MERCOSUR countries simultaneously reduced trade barriers between them and with the rest of the world. Second, prior to the establishment of MERCOSUR, Argentina and Brazil had already advanced toward liberalizing their bilateral trade. As mentioned above, these two countries had already reached in 1991 the initial 40 percent reduction of tariffs over MFN established in the MERCOSUR treaty. Table 3 shows that mutual preference margins between Argentina and Brazil had already increased before 1991, particularly of those in favor of Argentina in Brazil. Third, the Argentine and Brazilian economies are much larger than the Paraguayan and Uruguayan ones. Therefore, what happens to aggregate MERCOSUR trade flows is determined mostly by the changes that 
occur in exports and imports of the largest two countries. Fourth, the behavior of extra and intra-regional trade is affected by the real exchange rates of each country, both bilaterally with other MERCOSUR members and with the rest of the world. This is an issue that has rarely been systematically analyzed in the case of MERCOSUR. Future research should address the combined effect of trade preferences and relative changes in competitiveness on intraregional trade. ${ }^{14}$

Trade among the MERCOSUR countries and between each of them and the rest of the world expanded significantly in the early 1990s. In general, average annual growth rates in 1992-95 were higher than in the second half of the 1980s. Imports were particularly dynamic. This is shown in Table 5. In the table, average growth rates are shown for each of the periods of the construction of MERCOSUR and for

Table 5. Mercosur: Average Annual Growth of Exports and Imports (Percentages)

\begin{tabular}{|c|c|c|c|c|c|c|c|c|}
\hline & \multicolumn{4}{|c|}{ EXPORTS } & \multicolumn{4}{|c|}{ IMPORTS } \\
\hline & 1986-88 & 1989-91 & 1992-95 & 1986-95 & 1986-88 & 1989-91 & 1992-95 & $1986-95$ \\
\hline \multicolumn{9}{|l|}{ MERCOSUR } \\
\hline Total & 8.4 & 0.8 & 11.3 & 7.2 & 6.2 & 14.1 & 23.6 & 15.3 \\
\hline Extra-regional & 8.0 & -0.9 & 8.3 & 5.4 & 4.7 & 13.1 & 22.6 & 14.1 \\
\hline $\begin{array}{l}\text { Intra-regional } \\
\text { ARGENTINA }\end{array}$ & 14.5 & 20.3 & 29.6 & 22.1 & 18.5 & 20.0 & 28.4 & 22.8 \\
\hline Total & 2.9 & 9.5 & 15.0 & 9.6 & 11.7 & 15.9 & 24.9 & 18.1 \\
\hline Extra-regional & 2.2 & 6.6 & 9.1 & 6.3 & 10.0 & 15.9 & 24.4 & 17.4 \\
\hline Intra-regional & 9.5 & 31.2 & 36.1 & 26.1 & 18.8 & 15.5 & 26.4 & 20.8 \\
\hline $\begin{array}{l}\text { Of which Brazil } \\
\text { BRAZIL }\end{array}$ & 7.0 & 34.8 & 38.5 & 27.2 & 16.7 & 16.3 & 28.6 & 21.2 \\
\hline Total & 9.6 & -2.2 & 10.1 & 6.1 & 3.9 & 12.7 & 23.7 & 14.1 \\
\hline Extra-regional & 9.3 & -3.1 & 8.3 & 5.1 & 3.0 & 11.4 & 22.6 & 13.1 \\
\hline Intra-regional & 16.4 & 13.9 & 27.8 & 20.0 & 18.1 & 27.3 & 31.8 & 26.2 \\
\hline $\begin{array}{l}\text { Of which } \\
\text { Argentina }\end{array}$ & 11.2 & 25.0 & 28.6 & 22.1 & 14.4 & 33.2 & 34.7 & 27.8 \\
\hline PARAGUAY & & & & & & & & \\
\hline Total & 18.8 & 13.1 & 5.7 & 11.7 & 4.6 & 36.5 & 21.1 & 20.1 \\
\hline Extra-regional & 17.0 & 10.4 & -4.9 & 5.8 & 12.3 & 45.4 & 16.7 & 23.2 \\
\hline $\begin{array}{l}\text { Intra-regional } \\
\text { URUGUAY }\end{array}$ & 23.6 & 18.7 & 19.4 & 20.4 & -3.3 & 22.0 & 29.7 & 16.6 \\
\hline Total & 17.8 & 4.1 & 7.6 & 9.5 & 22.0 & 11.3 & 16.6 & 16.6 \\
\hline Extra-regional & 18.3 & -1.4 & 3.4 & 6.2 & 12.2 & 12.5 & 14.6 & 13.2 \\
\hline Intra-regional & 16.5 & 18.4 & 14.0 & 16.1 & 41.9 & 9.8 & 19.1 & 22.5 \\
\hline
\end{tabular}

Source: Own calculations on the basis of LAIA trade data. 
Figure 3.1. Argentina: Share of exports to MERCOSUR partners.

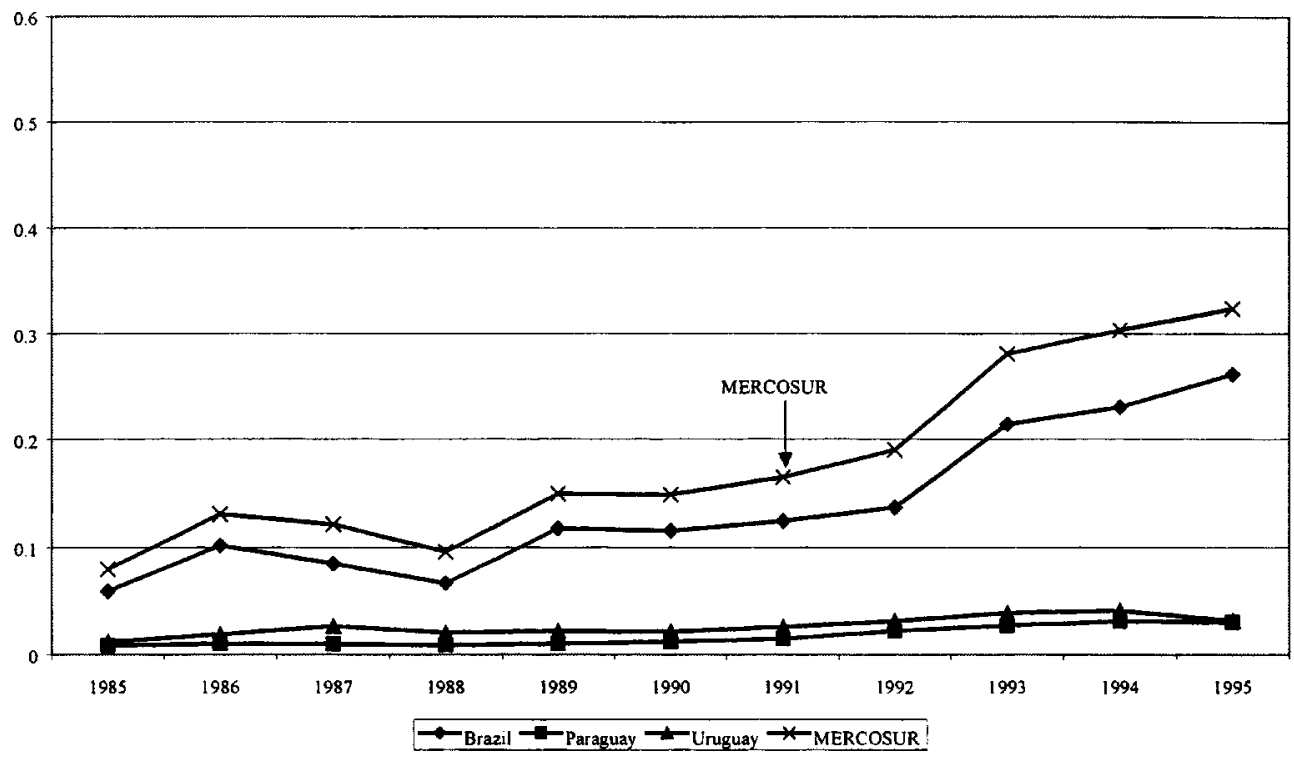

Figure 3.2. Brazil: Share of exports to MERCOSUR partners.

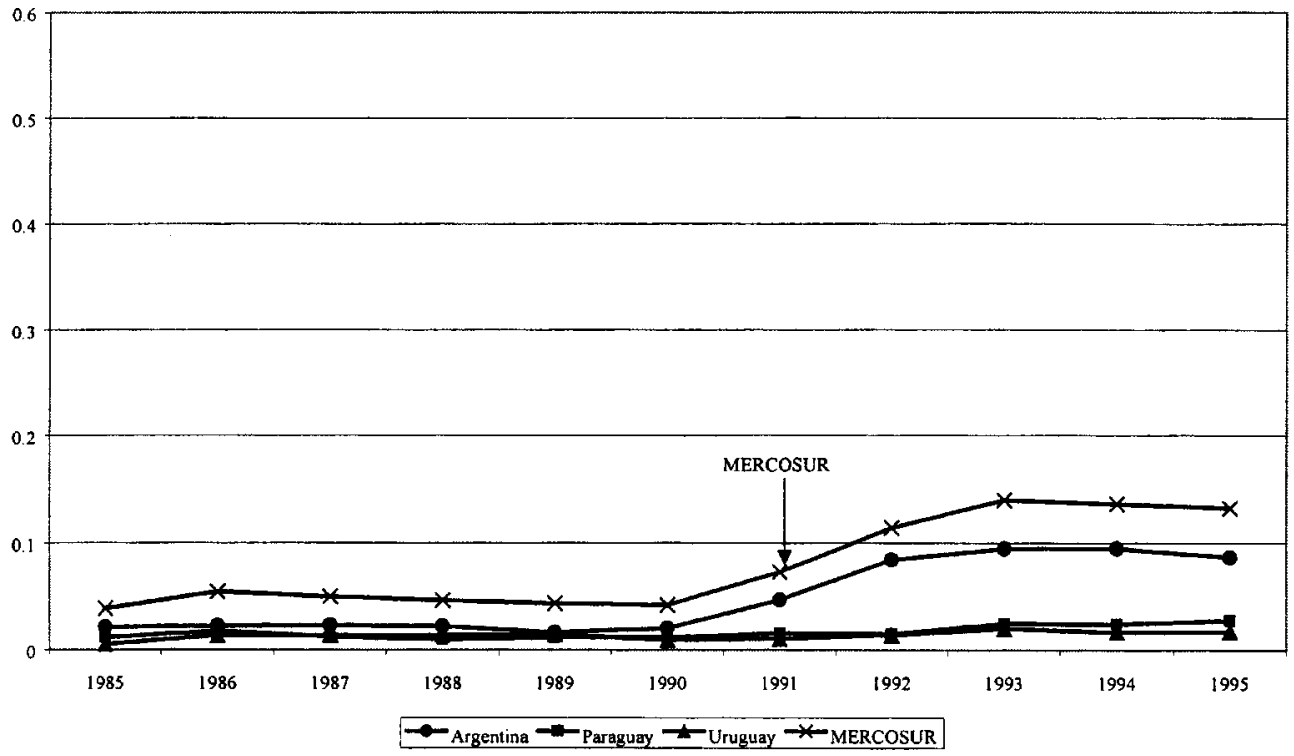

the whole 1985-95 decade.

For MERCOSUR in the aggregate and for its individual members the average

\footnotetext{
${ }^{14}$ This is potentially very important in the case of MERCOSUR because the two largest partners, Argentina and Brazil, went through hyperinflationary episodes and more than one attempt at stabilization in the $1985-95$ period that led to large fluctuations in real exchange rates.
} 
annual growth rate of intra-regional exports exceeded that of extra-regional ones for the entire decade and for the separate periods, even prior to the formalization of the trading bloc in 1991. Nevertheless, extra-regional exports expanded at double-digit rates per year on average in some sub-periods and in some countries. The growth rate of intra-MERCOSUR exports rose significantly between 1986-88 and 1992-95. In the cases of Argentina and Brazil, the more significant change in

Figure 3.3. Paraguay: Share of exports to MERCOSUR partners.

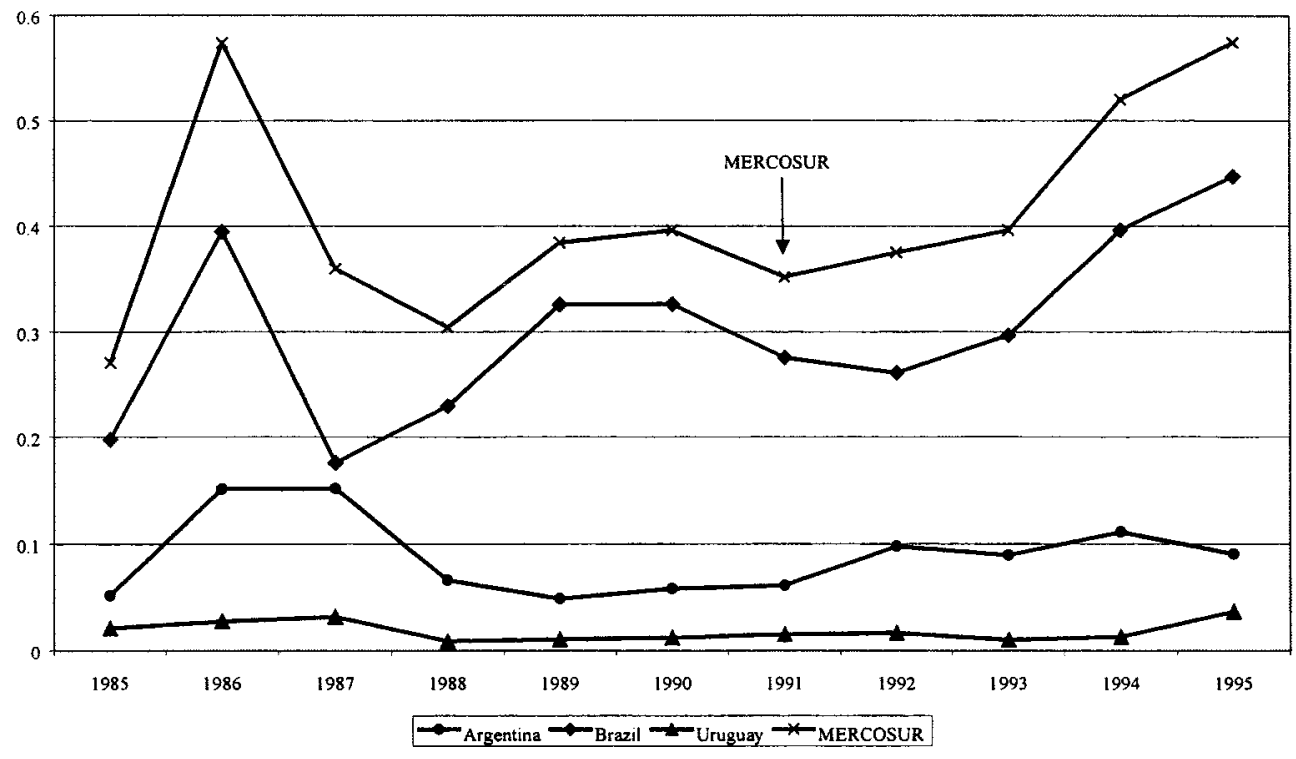

Figure 3.4. Uruguay: Share of exports to MERCOSUR partners.

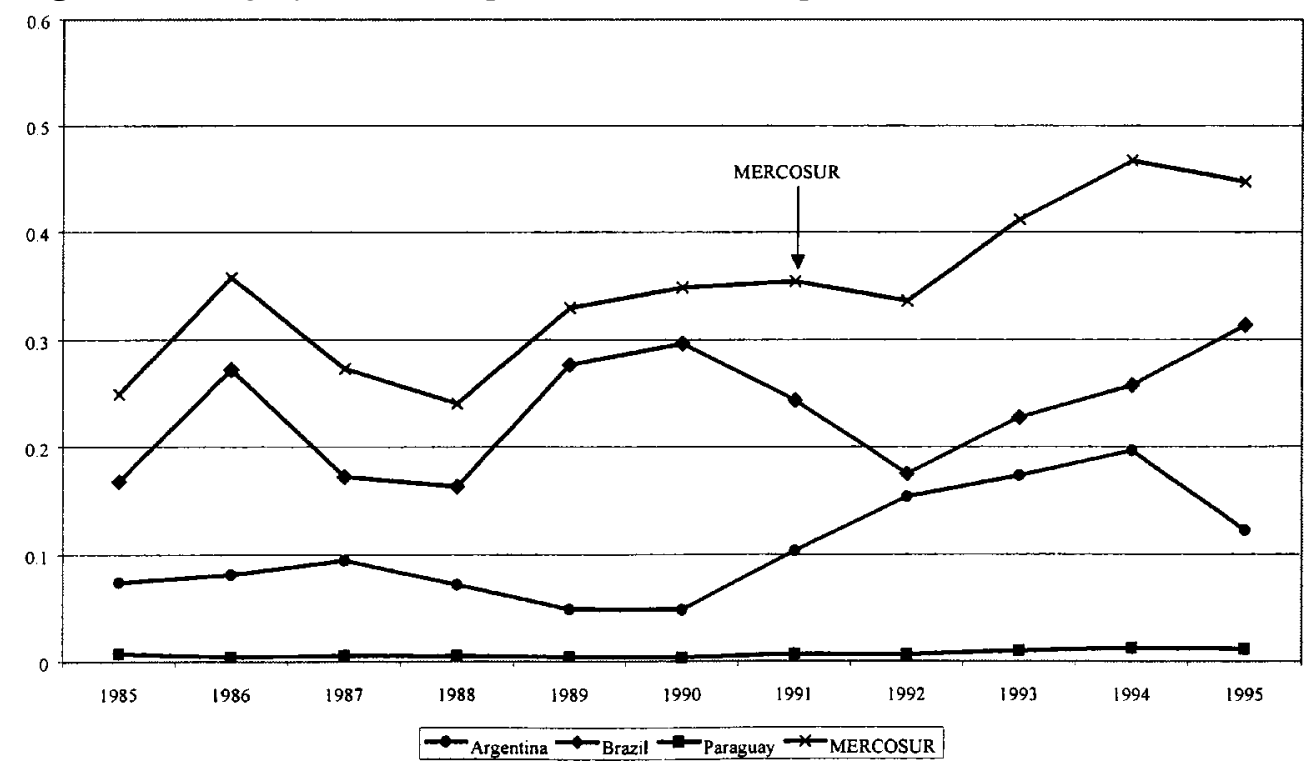


Figure 3.5. Argentina: Share of imports from MERCOSUR partners.

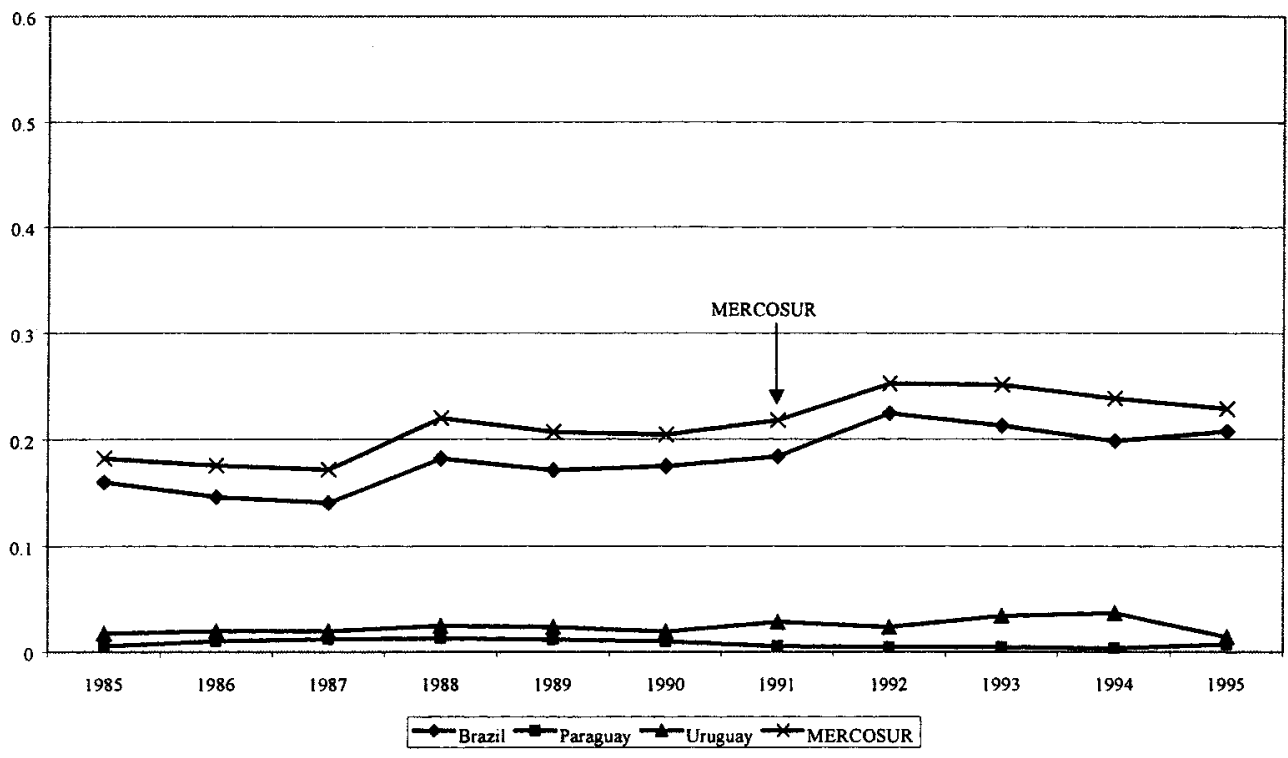

Figure 3.6. Brazil: Share of imports from MERCOSUR partners.

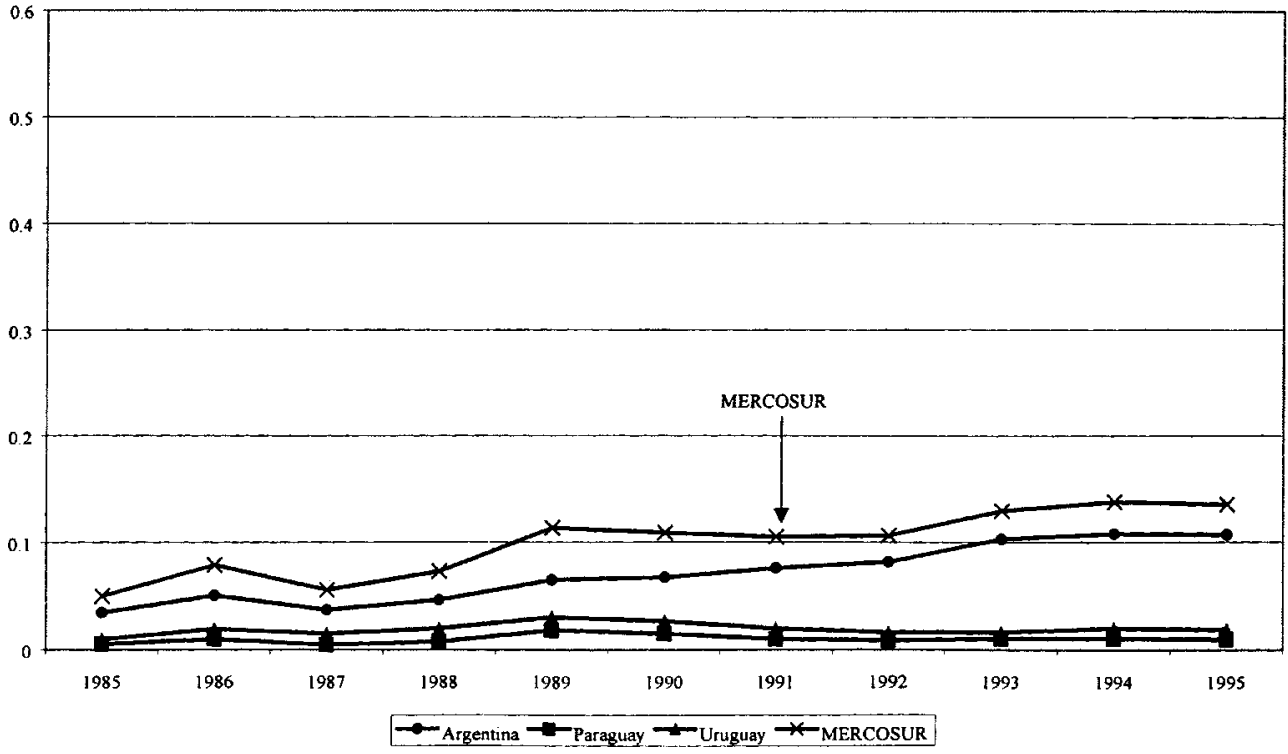

average growth of intra-MERCOSUR exports occurred prior to 1991. This may be the result of trade preferences in effect prior to the establishment of MERCOSUR or to investment in anticipation of trade liberalization in a preferential agreement, as discussed in Freund and McLaren (1999).

Graphs 3.1 and 3.2 show the rapid increase in the share of intra-regional exports 
in Argentina and Brazil, respectively. There are a number of differences between Argentina and Brazil in the evolution of this share. First, it started rising much earlier in the case of Argentina than in that of Brazil (after 1988 versus 1990). Second, in Argentina there are two years in which it rose significantly 1989 and 1992 and did so more moderately in the rest; in Brazil it increased very fast between 1991 and 1993, but then started to decline. When MERCOSUR was created, it was already the largest market of destination of Paraguayan and Uruguayan exports (see graphs 3.3 and 3.4).

In contrast to exports, both intra- and extra-regional import growth intensified in the successive periods from 1985 to 1995 . The average annual growth rates for total, extra-regional and intra-regional imports in 1992-95 were 3.8, 4.8 and 1.5 times those in 1986-88, respectively. This does not imply that intra-regional imports were not as dynamic as extra-regional ones. The data of Table 5 indicate that intra-MERCOSUR imports were already growing rapidly prior to 1988, when Argentina and Brazil decided to gradually remove all barriers to bilateral trade in their pre-MERCOSUR agreement. Although in 1985-95 intra-regional imports grew on average at a higher rate than extra-regional ones, the difference between the two is much smaller than in the case of exports.

Given this behavior of intra- and extra-regional imports, the change in the share of the former in total imports has not been as significant as in the case of exports. Graph 3.5 shows that there are again two years in which the share of intra-regional imports rose in Argentina: 1988 and 1993. However, in both cases it tended to decline in the following years so that at the end of the period it was only slightly higher than in the late 1980s. It should be noted that Argentina's share of intraMERCOSUR imports was relatively high compared to that of Brazil at the start of the process of integration (compare its level in 1985 in Graph 3.5 with that in Graph 3.6 for Brazil).

Brazils share of intra-MERCOSUR imports practically doubled between the late 1980s and the mid-1990s. It increased rapidly after 1987 and until 1989 when it stopped rising. However, the latter was due to imports from the two smaller partners. The share of imports from Argentina continued to increase until 1993.

The asymmetrical behavior of the shares of intra-regional exports and imports may be explained by the fact that as MERCOSUR was established in 1991 its member economies were at the same time liberalizing imports from other sources. As a result of this simultaneous opening to regional and world trade, imports from 
Figure 3.7. Paraguay: Share of imports from MERCOSUR partners.

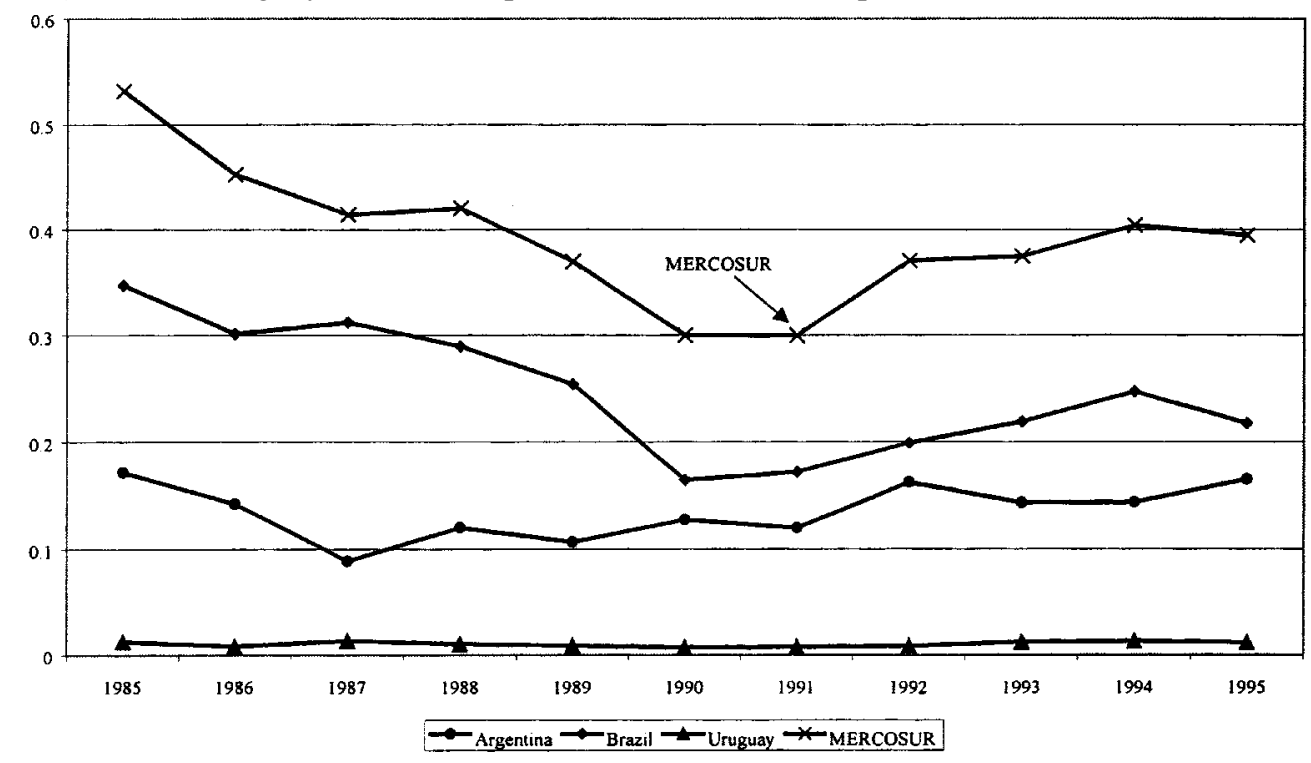

Figure 3.8. Uruguay: Share of imports from MERCOSUR partners.

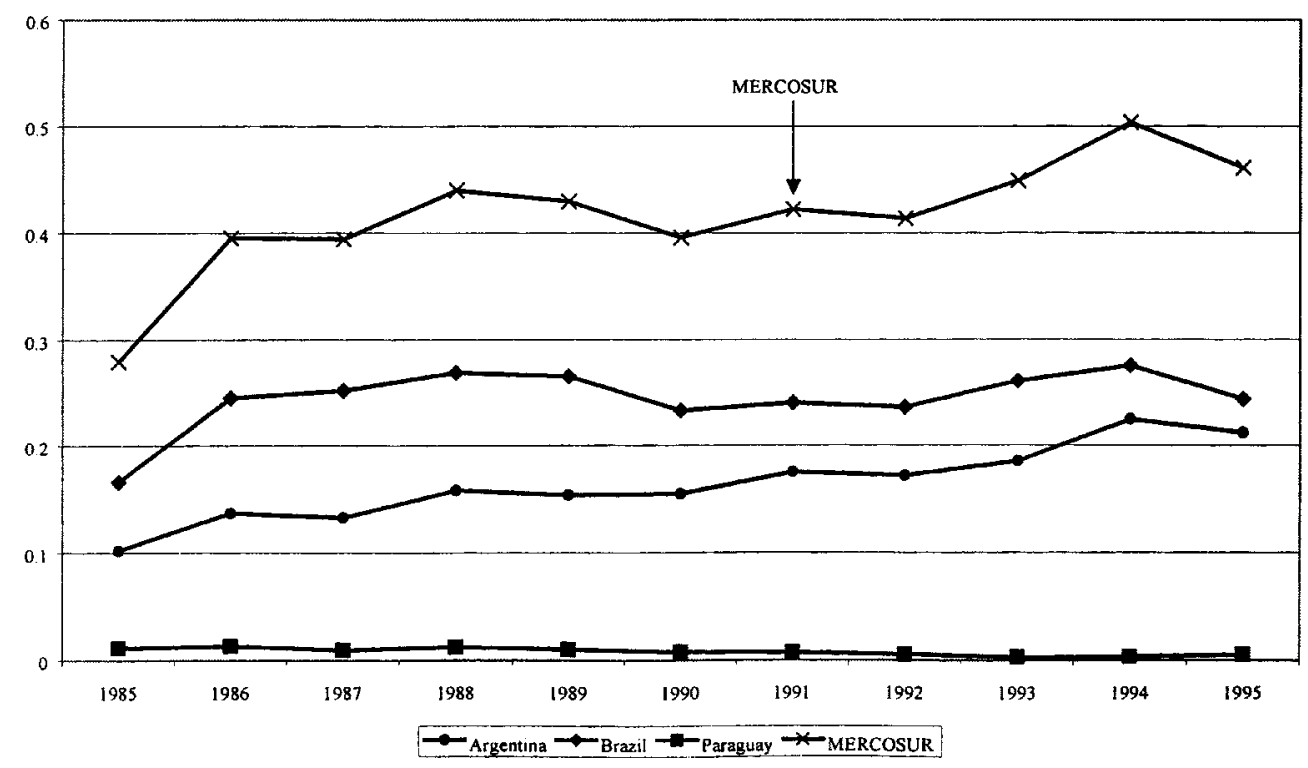

both the region and the world grew significantly. Fluctuations in real exchange rates are also likely to have had an effect on the relative incentive of exporting to MERCOSUR and to the rest of the world. 


\section{Concluding Remarks}

This paper has examined trade policies and trade flows in the MERCOSUR countries in detail since the mid-80s. Although MERCOSUR itself is a preferential trading arrangement, the magnitude of unilateral MFN tariff reductions is remarkable. ${ }^{15}$ The data in Section 2 are in conformity with Ethier's insight that the additional reductions in preferential tariffs are relatively modest in comparison with the aggressive unilateral reforms.

In Section 3, we have examined trade flows in MERCOSUR countries to determine whether various reform measures reviewed in Section 2 lead to the trade liberalization ex post. The examination clearly shows that there has been a dramatic trade expansion in these countries. It is interesting to note that the increase in trade can be observed both in intra-regional trade and in interregional trade, and therefore, trade policies in MERCOSUR countries are likely to have brought about trade expansion (or trade creation) rather than trade diversion. We believe that this study contributes to a deeper understanding of the New Regio-nalism, in particular, that MERCOSUR is not just a traditional preferential trading arrangement but a case in New Regionalism, where preferential liberalization is accompanied (or preceded) by aggressive unilateral trade reform by its members.

\section{Acknowledgements}

The authors would like to thank Brian Frantz for excellent research assistance and workshop participants at the Inter-American Development Bank. All errors are ours. All opinions expressed herein are those of the authors and should not be interpreted as reflecting the views of the Inter-American Development Bank.

Date accepted: June, 2000

\footnotetext{
${ }^{15}$ According to the figures in Table 1, while MFN tariffs in these MERCOSUR countries are obviously in a trend of dramatic decline, we observe a modest increase in MFN tariffs in very recent years. Although the increase is probably due to the short-term effort by each country to maintain the balance of payments during currency crises, such increase may be detrimental to the welfare of members and non-members, if such increase persists.
} 


\section{References}

Arocena, M. (1995), El Mercado Común del Sur: MERCOSUR, Documentos de Trabajo 203, Integration and Regional Programs Department, IDB, September.

Berlinski, J. (1994), Post Trade Liberalization Issues in Argentina, Serie Documentos de Trabajo 182, Instituto Torcuato Di Tella, May.

Chang, W. and L.A. Winters (1999), The Price Effects of Regional Integration: NonMember Reaction to (MERCOSUR (mimeo).

Estevadeordal, A., J. Goto and R. Saez (2000), “The New Regionalism in the America: The Case of Mercosur," INTAL-ITD Working Paper 5.

Ethier, W. (1998), “The New Regionalism,” The Economic Journal, Vol. 108, July.

Freund, C. and J. Mclaren (1999), On the Dynamics of Trade Diversion: Evidence from Four Trade Blocs, International Finance Discussion Papers No. 637, Board of Governors of the Federal Reserve System, June.

Fritsch, W. and G. Franco (1993), "The political economy of trade and industrial policy reform in Brazil in the 1990s," Serie Reformas de Política Pública 6, ECLAC.

GATT (1992a), Trade Policy review: Argentina 1992, Geneva, May.

GATT (1992b), Trade Policy review: Uruguay 1992, Geneva, November.

Goto, J. and K. Hamada (1998), "Economic Integration and the Welfare of Those who are

Left Behind: An Incentive-Theoretic Approach," Journal of Japanese and International Economies.

Goto, J. and K. Hamada (1999), "Regional Economic Integration and Article XXIV of the

GATT," Review of International Economics, November

INTAL (1996), Report MERCOSUR No.1, IDB, July-December.

INTAL (1997), Report MERCOSUR No.3, IDB, July-December.

Primo Braga, C., J. Nogues and S. Rajapatirana (1995), Latin America and the Caribbean in the World Economy. Trade reforms, Progress and Risks of Reversal, Annual World

Bank Conference on Development in Latin America and the Caribbean, Rio de Janeiro, June.

Viner, J. (1950), The Customs Union Issue, New York: Carnegie Endowment for International Peace.

WTO (1997a), Trade Policy Review: Brazil, Geneva, March.

WTO (1997b), Trade Policy Review: Paraguay, Geneva, October.

WTO (1998), Trade Policy Review: Uruguay, Geneva.

WTO (1999), Trade Policy Review: Argentina, Geneva.

Yeats, A. (1998), "Does MERCOSURs Trade Performance Raise Concerns about the Effects of Regional Trade Arrangements?," The World Bank Economic Review. 